\title{
PSIKOEDUKASI ONLINE BAGI MASYARAKAT UNTUK MEREDAKAN STRES DI TENGAH PANDEMIK COVID-19
}

\author{
${ }^{1}$ Heni Gerda Pesau, ${ }^{2}$ Meidy M. L. Panglewai \\ ${ }^{1,2}$ Universitas Atma Jaya Makassar \\ ${ }^{1}$ heni_gerda@lecturer.uajm.ac.id \\ ${ }^{2}$ meidy_panglewai@lecturer.uajm.ac.id
}

\begin{abstract}
The COVID-19 pandemic has caused many changes in various aspects of people's lives. The changes caused psychological problems, one of which is stress. Stress conditions experienced by individuals need to be handled so as not to prolong or cause other psychological symptoms. One of the interventions that can be done in the midst of a pandemic is online psychoeducation. Based on this, the target of online psychoeducation carried out was the general public who were willing to become participants. The goal of online psychoeducation activities was to increase participants' knowledge of stress conditions and techniques that can be used to relieve stress. Psychoeducation was given in two methods, namely interactive lectures that discussed stress recognition and modeling techniques related to stress relief techniques. The results of the evaluation of the activities showed that more than $50 \%$ of participants gave positive responses to the material presented and the participants' expectations were achieved after participating in online psycho education. Thus it can be concluded that providing online psychoeducation could provide knowledge related to stress conditions experienced and techniques that can be applied to relieve stress experienced during the current COVID-19 pandemic.
\end{abstract}

Keywords: COVID-19, Stress, Psychoeducation, Online, Technique

\section{PENDAHULUAN}

Penyebaran pandemik COVID-19 di Indonesia yang mulai diumumkan sejak 2 Maret 2020 memberi dampak perubahan pada berbagai aspek kehidupan masyarakat luas (Nuraini, 2020). Survei terkait dampak COVID-19 yang dilakukan di Indonesia menemukan beberapapa perubahan yang paling sulit dihadapi akibat COVID-19 yaitu rasa aman, bersosialisasi, dan meninggalkan rumah (Ardiyanti, Bramanti, Mohanty, Narayan, \& Saputro, 2020). Berbagai perubahan yang dialami menyebabkan individu dapat menunjukkan respon umum baik secara langsung maupun tidak langsung seperti takut akan jatuh sakit atau meninggal, takut kehilangan mata pencaharian ataupun tidak dapat berkeja selama isolasi diri, merasa tidak mampu melindungi orang yang disayangi dan takut kehilangan orang yang dicintai akibat virus, merasa tidak berdaya, bosan, kesepian, mengalami gejala distress lainnya seperti masalah tidur, PTSD, depresi, stres akut, kecemasan maupun rasa takut yang ditimbulkan akibat menyebarnya banyak informasi yang kurang tepat terkait pandemik COVID-19 (IASC, 2020; NYC Health, 2020; Taylor, 2019; Torales, O’Higgins, Castaldelli-Maia, \& Ventriglio, 2020).

Mulculnya pandemi COVID-19 menyebabkan masa krisis yang menimbulkan stres pada seluruh populasi (World Health Organization, 2020). Stres pada dasarnya merupakan respon yang mendorong individu untuk bertahan menghadapi ancaman yang terjadi (Greenberg, 2017). Stres juga dapat didefinisikan sebagai segala jenis perubahan yang menyebabkan ketegangan fisik, emosional, atau psikologis yang membutuhkan perhatian atau tindakan (Scott, 2020). Dalam hal ini, COVID-19 sendiri serta berbagai perubahan sebagai dampaknya dapat menjadi sumber stres bagi individu.

Stres yang dialami individu dapat berupa stres akut yaitu respon terhadap stresor jangka pendek yang dapat menghasilkan gejala kecemasan dan psikosomatis; yang kemudian respon tersebut dapat berlangsung dalam waktu yang lama yang disebut stres kronis. Stres yang berlangsung lama dan tidak ditangani tersebut dapat memberi dampak, 
seperti mengganggu fungsi otak, memengaruhi kemampuan belajar, memori, dan mood; menyebabkan masalah tidur; serta dapat mengganggu sistem imun sehingga lebih rentan terserang penyakit, dan meningkatkan resiko darah tinggi, stroke dan serangan jantung (Greenberg, 2017). Kondisi kesehatan mental pada masyarakat menjadi lebih rapuh di masa pandemik, terutama pada individu yang sudah memiliki bawaan masalah psikologis (Torales, O'Higgins, Castaldelli-Maia, dan Ventriglio, 2020). Oleh karena itu, respon stres yang dirasakan individu akibat COVID-19 perlu segera ditangani karena dapat menyebabkan masalah lain yang tidak hanya berdampak pada mental tapi juga kesehatan fisik.

Berdasarkan hal tersebut, maka intervensi psikologis berbasis komunitas dapat diaplikasikan untuk mengurangi gejala-gejala psikologis pada orang dewasa dalam melewati masa-masa pandemik. Dukungan psikologis yang diterima oleh individu melalui intervensi psikologis dapat membantu untuk meredakan gejala awal permasalahan psikologis yang timbul akibat masa pandemik, maupun untuk mencegah kembalinya kondisi traumatis dan masalah psikologis bawaan yang dimiliki individu sebelumnya. Individu yang mengalami stres maupun trauma akibat menyaksikan orang terdekatnya meninggal akibat virus COVID-19 juga dapat ditangani melalui intervensi psikologis (Taylor, 2019). Selain itu, intervensi psikologis juga perlu diberikan untuk meningkatkan perhatian masyarakat terhadap kesehatan, dimana hasil survei terkait dampak COVID-19 menunjukkan kesehatan mendapat perhatian yang lebih rendah dibandingkan dampak pada kehidupan sehari-hari, keamanan finansial, dan ekonomi (Ardiyanti, Bramanti, Mohanty, Narayan, \& Saputro, 2020).

Intervensi psikologis untuk meredakan stres dapat diberikan dalam berbagai bentuk salah satunya teknik relaksasi, yaitu salah satu teknik yang dapat digunakan untuk mengurangi tekanan dan melepaskan tegangan fisik dan psikis yang berlebihan akibat stres dan menetralkan atau menenangkan agar sistem tubuh kembali normal (Davis, Eshelman, \& McKay, 2008). Akan tetapi, penerapan intervensi psikologis tidak memungkinkan untuk dilakukan secara tatap muka langsung karena adanya kebijakan pembatasan fisik dari pemerintah Indonesia selama masa pandemik COVID-19 (Prabowo, 2020). Kondisi tersebut menyebabkan banyak peralihan aktivitas dari tatap muka langsung ke dalam bentuk jarak jauh melalui teknologi internet (online). Oleh karena itu, intervensi psikologis juga dilakukan melalui telemedicine (telehealth) maupun telekonseling, yaitu suatu bentuk penyampaian informasi dan penanganan yang berkaitan dengan kesehatan fisik maupun mental yang dilakukan secara jarak jauh melalui perangkat komunikasi dan sambungan internet. Salah satu bentuk layanan psikologis yang dapat dilakukan secara jarak jauh dan melibatkan masyarakat luas adalah psikoedukasi berbasis komunitas.

Berdasarkan Kode Etik Psikologi (Himpsi, 2010) pasal 69, psikoedukasi diartikan sebagai suatu kegiatan yang dilakukan untuk meningkatkan pemahaman dan atau keterampilan sebagai usaha pencegahan dari munculnya dan atau meluasnya gangguan psikologis di suatu kelompok, komunitas, atau masyarakat. Intervensi berbentuk psikoedukasi yang dilakukan secara online merupakan langkah utama yang dapat dilakukan di masa pandemik untuk meredakan gejala-gejala psikologis dan meningkatkan kesehatan mental masyarakat (Smith, Harman, \& Brenner, 2020). Adapun keuntungan yang diperoleh dari pelaksanaan psikoedukasi secara online adalah masyarakat merasa terbantu karena mendapatkan akses yang lebih mudah untuk menanyakan informasi maupun menyampaikan keluhannya secara langsung kepada profesional kesehatan mental tanpa perlu meninggalkan rumah. Psikoedukasi online sebagai salah satu bentuk intervensi memiliki dampak yang signifikan dalam membantu menangani masalah 
kesehatan mental dan meningkatkan resiliensi individu, dimana manfaat positif yang dihasilkan serupa dengan intervensi yang dilakukan secara tatap muka (Maryam, Yazdani, \& Valibeigi, 2020). Berdasarkan beberapa temuan sebelumnya, maka pengabdian masyarakat yang akan dilakukan dalam kegiatan ini mengacu pada bentuk intervensi online, yaitu psikoedukasi online yang diikuti oleh individu agar mampu memberdayakan diri di tengah kondisi pandemik COVID-19. Dengan demikian, maka tujuan dari kegiatan psikoedukasi online tersebut adalah untuk menyebarluaskan pengetahuan dasar tentang stres kepada masyarakat serta teknik-teknik relaksasi untuk meredakan stres yang dapat diterapkan secara mandiri. Hal ini akan memampukan individu untuk tetap berdaya di tengah kondisi pandemik COVID-19.

\section{METODE}

Sasaran kegiatan ini adalah masyarakat Indonesia (khususnya yang berada di sekitar Kota Makassar) yang berminat menjadi peserta psikoedukasi online. Pada dasarnya tidak ada batasan wilayah karena pandemik COVID-19 dialami oleh seluruh masyarakat Indonesia dan pelaksanaan secara online sehingga memungkinkan seluruh masyarakat ikut perpartisipasi dengan kriteria memiliki jaringan internet dan aplikasi yang digunakan sehingga mampu mengakses kegiatan psikoedukasi. Penyampaian materi psikoedukasi seluruhnya dilakukan secara online memakai platform Cisco Webex, sehingga peserta dapat mengikuti psikoedukasi dari tempatnya masing-masing dengan memakai laptop atau smartphone yang dimiliki. Bentuk penyampaian materi dilakukan melalui:

1. Ceramah interaktif

Ceramah interaktif merupakan salah satu metode pelatihan, yang dilakukan dengan pemberian materi secara efisien, pembentukan pola perilaku, mendorong minat dan meningkatkan motivasi serta pengetahuan, semangat dan kebebasan berekspresi peserta (Yakovleva \& Yakovlev, 2014). Bentuk ceramah digunakan untuk menyampaikan dan menjelaskan materi-materi inti yaitu mengenali stres. Ceramah dibuat semenarik mungkin agar peserta mudah memahami isi materi dan termotivasi untuk menerima materi yang disampaikan. Ceramah dilakukan dengan media pendukung slide power point yang dibagikan di layar gawai masing-masing peserta selama psikoedukasi online berlangsung.

2. Pemeragaan

Bentuk lain yang digunakan selama psikoedukasi adalah pemeragaan, yaitu pengembangan pengetahuan prosedural peserta didik, dari observasi dan imitasi hingga otonomi yang berfokus pada teknik dan prosedur praktis (McLain, 2019). Oleh karena itu, pemeragaan merupakan metode yang tepat untuk agar peserta dapat memahami dan mempraktikkan teknik-teknik untuk meredakan stres. Terdapat tiga teknik yang secara langsung dipraktikkan bersama-sama secara online dengan dipandu oleh pemateri yaitu progressive muscle relaxation, visualisasi atau imagery, dan emotional freedom techniques (EFT) atau "tapping".

Tabel 1: Tahap Pelaksanaan Kegiatan

\begin{tabular}{|l|c|l|}
\hline \multicolumn{1}{|c|}{ Tahap } & Waktu & \multicolumn{1}{c|}{ Kegiatan } \\
\hline $\begin{array}{l}\text { Persiapan } \\
\text { Pelaksanaan: } \\
\text { April } 2020\end{array}$ & - & $\begin{array}{l}\text { - Pembuatan modul kegiatan, } \text { online poster, power point slide, } \\
\text { dan kuesioner evaluasi. } \\
\text { - Persiapan tim pelaksana dan pembagian tugas } \\
\text { - Membuat grup peserta melalui Whatsapp Group }\end{array}$ \\
\hline $\begin{array}{l}\text { Persiapan } \\
\text { Teknis: } \\
28 \text { Mei } 2020\end{array}$ & $17.00-18.30$ & $\begin{array}{l}\text { - Pertemuan bersama tim untuk membahas teknis pelaksanaan } \\
\text { dan modul materi } \\
\text { - Menyiapkan tautan jaringan untuk psikoedukasi online }\end{array}$ \\
\hline
\end{tabular}




\begin{tabular}{|c|c|c|}
\hline $\begin{array}{l}\text { Pelaksanaan: } \\
29 \text { Mei } 2020\end{array}$ & $09.45-12.10$ & $\begin{array}{l}\text { - Peserta mulai bergabung di meeting room } \\
\text { - Pembukaan kegiatan } \\
\text { - Materi sesi 1: Mengenali Stres } \\
\text { - Materi sesi 2: Teknik Meredakan Stres } \\
\text { - Sesi tanya jawab } \\
\text { - Penutup kegiatan dan pengisian form evaluasi }\end{array}$ \\
\hline
\end{tabular}

Sebelum pelaksanaan, poster kegiatan disebarluaskan melalui media sosial untuk mengumpulkan peserta kegiatan. Peserta yang bersedia mengikuti psikoedukasi online melakukan registrasi melalui google form. Psikoedukasi online yang diberi judul "Dancing in The Storm" dilaksanakan pada hari Jumat, 29 Mei 2020 pukul 10.00 - 12.10 WITA melalui platform Cisco Webex. Tim pelaksana kegiatan melakukan sesi online dari Kota Makassar. Jumlah peserta awal yang melakukan registrasi sebanyak 60 orang dari usia 15 - 52 tahun yang berasal dari berbagai kota di Indonesia dan terdiri atas berbagai tingkat pendidikan dan profesi. Pada akhir kegiatan, jumlah peserta yang terdata melakukan pengisian form evaluasi sebanyak 32 orang.

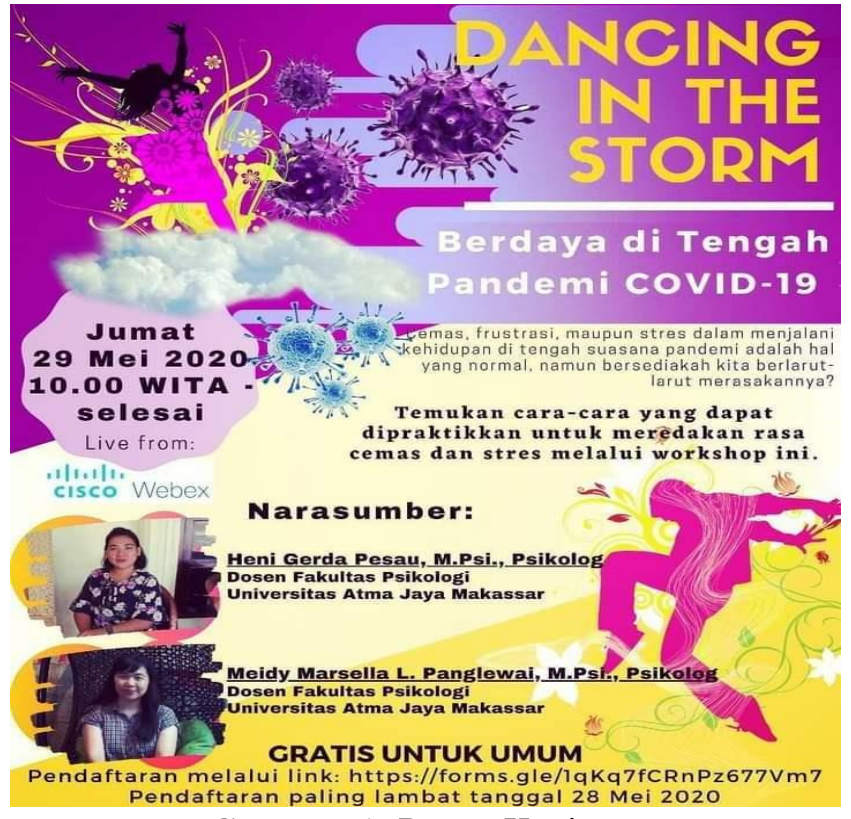

Gambar 1: Poster Kegiatan

\section{HASIL KARYA UTAMA DAN PEMBAHASAN}

Pandemik COVID-19 menyebabkan perubahan dalam segala aspek kehidupan masyarakat Indonesia. Perubahan tersebut menyebabkan masyarakat mengalami masalah psikologis, salah satunya adalah stres. Oleh karena itu, perlu dilakukan upaya untuk meredakan stres yang dialami salah satunya dengan pemberian psikoedukasi online "Dancing in the Storm". Psikoedukasi sebagai aktivitas pemberian layanan umum di bidang psikologi memiliki cakupan yang luas di dalam penerapannya di lapangan, di antaranya sebagai serangkaian kegiatan pelayanan kepada masyarakat; memberikan layanan informasi tentang psikologi kepada publik sehingga psikoedukasi juga dapat diartikan sebagai pendidikan publik; serta pemberian layanan informasi kepada masyarakat luas tentang berbagai pengetahuan dan/atau keterampilan yang berguna untuk menghadapi masalah sehari-hari (Nelson-Jones dalam Supratiknya, 2011). Pelaksanaan psikoedukasi secara online juga tetap dapat memberi manfaat sama halnya dengan pemberian psikoedukasi secara langsung (Maryam, Yazdani, \& Valibeigi, 2020). 
Hasil pelaksanaan kegiatan menunjukkan tujuan kegiatan psikoedukasi online dapat tercapai karena seluruh materi yaitu pengenalan tentang stres dan pemeragaan teknik meredakan stres dapat disampaikan. Secara umum, kegiatan psikoedukasi online berjalan lancar sesuai dengan jadwal yang telah direncanakan. Berdasarkan hasil tersebut pula, kegiatan psikoedukasi online telah memenuhi beberapa aspek yang sehingga dapat dikatakan berhasil dilaksanakan. Hal ini dapat terlihat dari beberapa indikator keberhasilan, antara lain:

a. Terlaksananya seluruh kegiatan psikoedukasi online sesuai jadwal dari awal sampai akhir

b. Sebagian besar peserta menyatakan puas atas kegiatan psikoedukasi online ini yang dapat dilihat dari persentase pada masing-masing aspek evaluasi melalui Gambar 2 sebagai berikut:

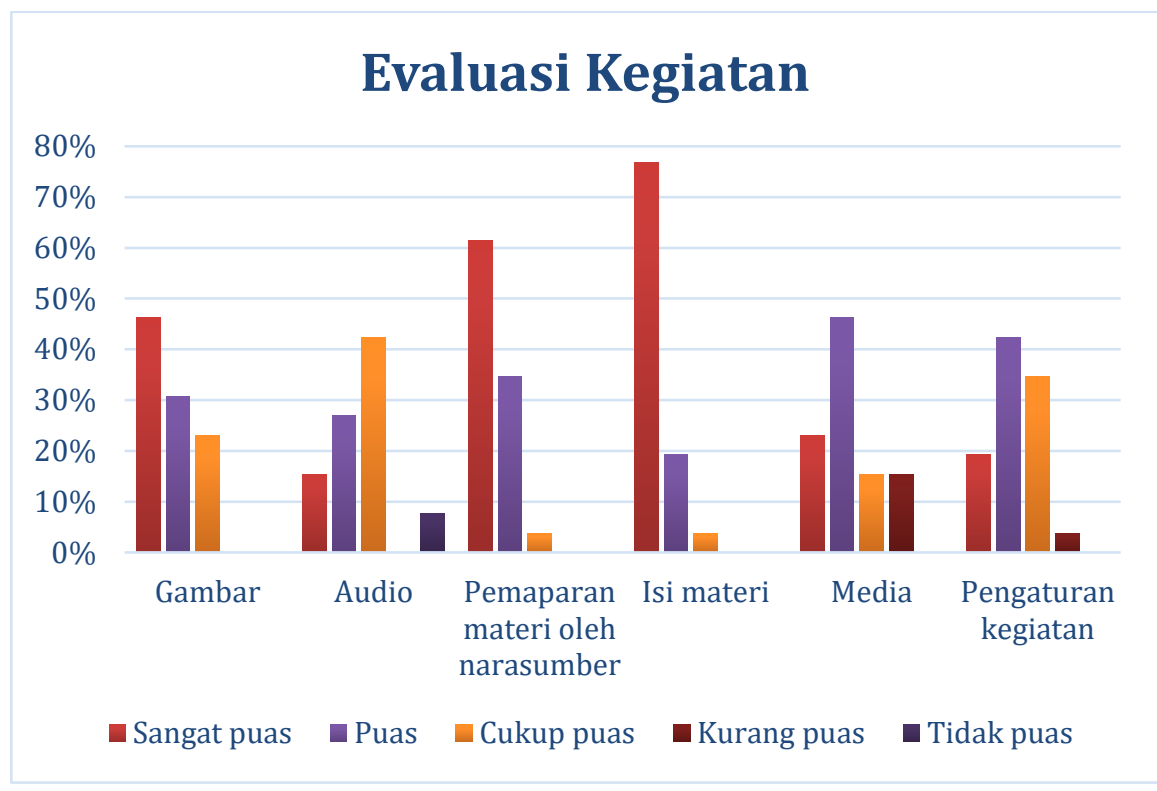

Gambar 2: Grafik Evaluasi Kegiatan

Berdasarkan grafik tersebut dapat dilihat peserta psikoedukasi menyatakan puassangat puas terhadap kualitas gambar sebanyak 76\%, 42.3\% menyatakan cukup puas dengan kualitas audio, dan 69\% menyatakan puas hingga sangat puas dengan media yang digunakan. Adapun peserta yang menyatakan kurang puas dengan media dan audio yang digunakan yaitu masing-masing sekitar $15 \%$ disebabkan masalah jaringan internet yang umum dialami pada pelaksanaan kegiatan secara online. Kendala teknis dan jaringan merupakan hal lumrah yang dapat terjadi dan salah satu kelemahan dari pelaksanaan kegiatan secara online. Pemberian materi yang dilaksanakan secara online memiliki kelebihan seperti kesempatan untuk mengikuti kegiatan tanpa harus berada di tempat yang sama dan bisa diikuti oleh peserta dari berbagai latar belakang, namun juga memiliki kekurangan, salah satunya masalah teknis, dimana untuk mengakses kegiatan memerlukan jaringan internet yang cukup kuat, sebaliknya jaringan internet yang lemah akan memengaruhi seberapa cepat koneksi dan partisipasi di ruang pertemuan (Purdue University Global, 2020)

Peserta sebanyak kurang lebih $61 \%$ menyatakan puas dengan pengaturan kegiatan yang tidak lepas dari kerjasama tim pelaksana mulai dari persiapan hingga pelaksanaan kegiatan. Hal tersebut dapat disebabkan persiapan atau simulasi yang dilakukan tim pelaksana sebelum kegiatan. Simulasi merupakan sebuah metode untuk menghasilkan 
karakteristik nyata dari suatu situasi atau kejadian; sebuah alat dalam pendidikan; kesempatan untuk meningkatkan dan menyesuaikan aspek-aspek dari kondisi nyata yang memfasilitasi belajar dan latihan (Chernikova dkk, 2020). Oleh karena itu, pelaksana psikoedukasi online melakukan simulasi sebelum kegiatan untuk meminimalisir kendala yang dapat terjadi selama pelaksanaan walaupun kendala teknis juga masih memungkinkan untuk terjadi baik dari pelaksana maupun peserta.

Selanjutnya pemaparan materi oleh narasumber dan isi materi masing-masing sekitar 95\% peserta menyatakan puas-sangat puas juga berdasarkan kesan peserta yang menyatakan materi disampaikan dengan baik, terstruktur, dan detail. Hasil tersebut menunjukkan bahwa materi yang diberikan sesuai dengan tujuan pelaksanaan karena didukung cara atau metode yang digunakan dalam pemaparan materi yaitu dalam bentuk ceramah interaktif dan pemeragaan. Ceramah interaktif merupakan salah satu metode dalam pendidikan dengan membrikana lebih banyak pengalaman interaksi antara gurusiswa atau pemateri dan peserta, dimana jika dibandingkan dengan ceramah tradisional, dimana guru berbicara dan siswa mendengar, pada ceramah interaktif terjadi komunikasi dua arah atau timbal - balik sehingga interaksi yang dibangun selama proses belajar meningkat bukan hanya interaksi manusia melainkan juga dengan bahan atau materi (Murphy \& Sharma, 2010).

Oleh karena itu, materi psikoedukasi online dapat lebih efektif diterima oleh para peserta psikoedukasi karena peserta tidak hanya pasif menerima, karena selama kegiatan, pemateri juga memberikan pertanyaan atau informasi agar peserta juga aktif dengan memberikan tanggapan langsung. Selain itu, digunakan metode pemeragaan pada sesi kedua. Pemeragaan merupakan salah satu teknik yang bertujuan mengembangkan pengetahuan peserta didik yang berfokus pada teknik dan prosedur praktis (McLain, 2019). Pemeragaan dinilai sebagai metode yang efektif digunakan untuk menjelaskan teknik-teknik meredakan stres, karena pada sesi ini peserta tidak hanya perlu mengetahui tapi juga mempraktikkan atau melakukan langsung gerakan-gerakan pada setiap teknik yang dicontohkan oleh pemateri.

Hasil evaluasi juga menunjukkan peserta puas dengan isi materi yang menarik dan sesuai dengan kebutuhan para peserta, yaitu sesi 1 tentang Mengenali Stres dan sesi 2 tentang Teknik Meredakan Stres. Sesi 1 diawali dengan pemberian skala untuk mengetahui tingkat stres peserta lalu dilanjutkan dengan pemaparan materi tentang stres dan stresor, tipe dan mekanisme stres, serta karakteristik dan bentuk coping stres. Stres dapat diartikan sebagai mekanisme pertahanan terhadap stresor atau sumber stres yang dapat berbentuk stresor fisik yaitu berkaitan dengan kondisi fisik seperti penyakit atau kecelakaan yang menyebabkan individu kehilangan fungsi; stresor psikologis berhubungan dengan bagaimana individu meninterpretasi kejadian dalam hidup; dan stresor psikososial dari interaksi individu dan masyarakat atau sosial yang membutuhkan penyesuaian terhadap lingkungan dan budaya (Chen, 2017), khususnya dalam hal ini pandemik COVID-19 serta dampaknya. Peserta yang mendapat penjelasan tersebut dapat memahami stres dan bentuk stres serta berbagai situasi atau faktor yang dapat menyebabkan stres.

Selain itu, pemateri juga menjelaskan tentang mekanisme stres yang dimulai dari adanya berbagai kejadian atau situasi hidup yang menjadi stresor atau pemicu stres, persepsi dan evaluasi, respon stres, konsekuensinya (Chen, 2017). Peserta juga dapat melakukan deteksi atau mengidentifikasi stres yang dialami melalui berbagai karakteristik yang juga dijelaskan dalam pemberian materi sesi I, yaitu karakteristik fisiologis seperti jantung berdebar-debar, berkeringat, mulut kering, kelelahan, insomnia, mual, pusing, kehilangan selera makan, tekanan darah tinggi, kehilangan atau 
bertambahnya berat badan. Kedua, karakteristik kognitif ditandai dengan memori yang terganggu, disorientasi, tuntutan yang tidak realistis, pemikiran yang tidak logis, fantasi yang berlebihan, dan seterusnya; ketiga, aspek emosional ditandai dengan rasa takut, cemas, panik, menyesal, marah, tidak berdaya, depresi, tidak sabar; dan keempat, aspek perilaku ditunjukkan dengan menangis, mengamuk, menarik diri, penyalahgunaan obat, impulsif, hiperaktif, agresi, dan seterusnya (Chen, 2017).

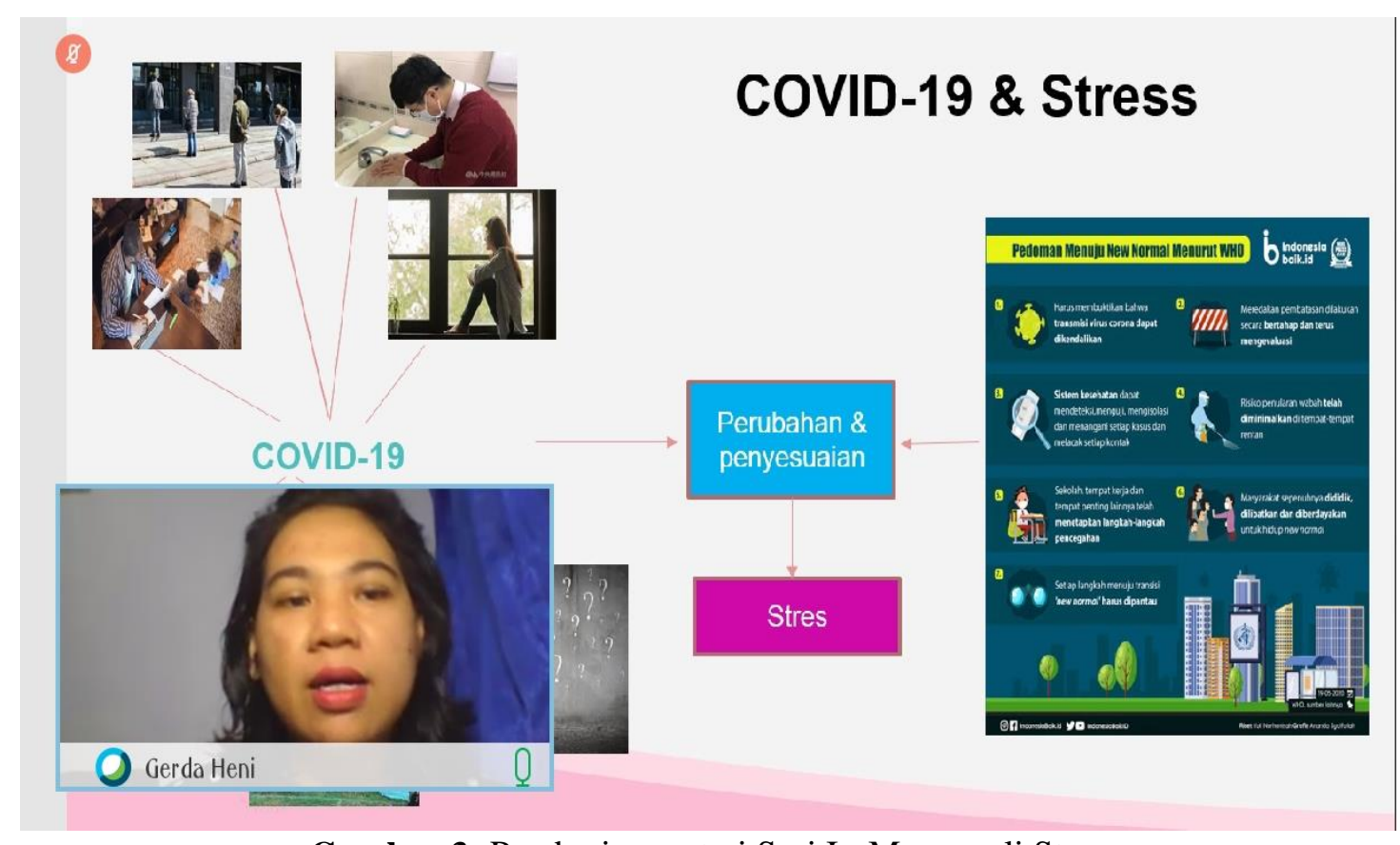

Gambar 3: Pemberian materi Sesi I - Mengenali Stres

Selanjutnya pada sesi II berisi tentang teknik-teknik yang dapat dilakukan peserta untuk meredakan stres. Penyampaian materi tentang teknik-teknik meredakan stres tersebut dilakukan sambil memeragakan secara bersama-sama agar peserta dapat lebih memahaminya serta langsung merasakan dampak ringannya, yaitu merasa lebih tenang pada saat kegiatan berlangsung. Teknik relaksasi yang diberikan terdiri atas beberapa bentuk seperti, progressive muscle relaxation, visualisasi atau imagery, dan emotional freedom techniques (EFT) atau "tapping".

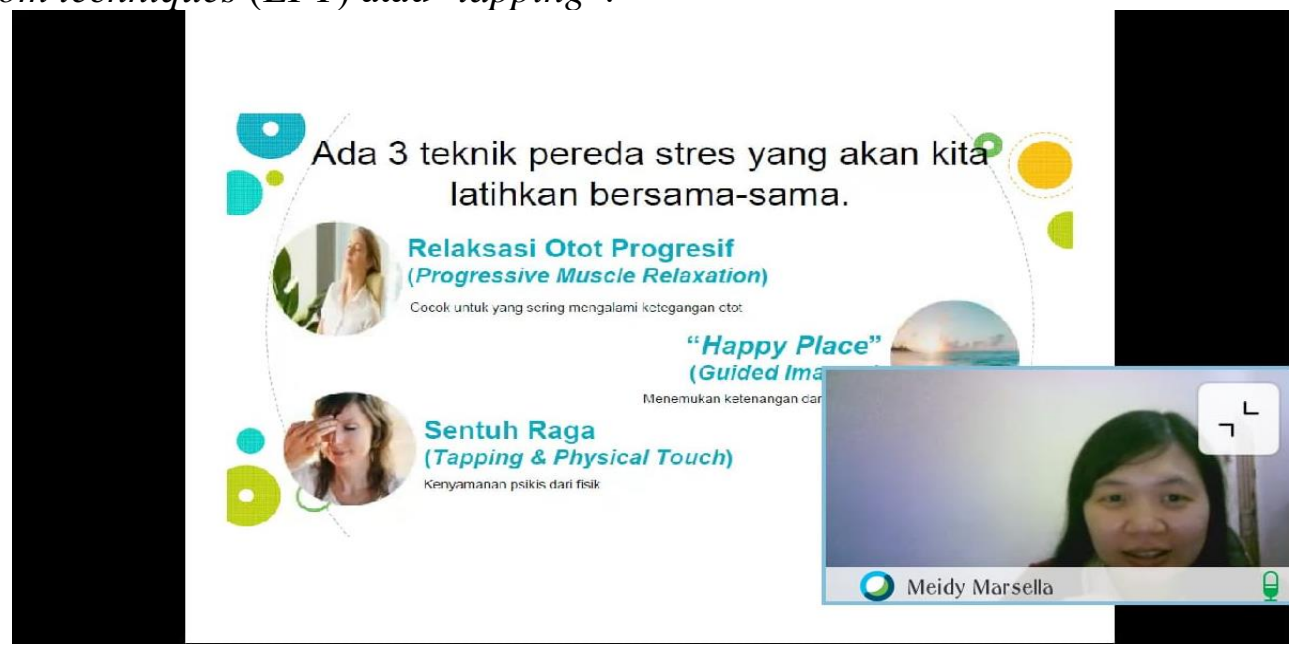

Gambar 4: Pemberian materi Sesi II - Teknik Meredakan Stres 
Relaksasi otot progresif atau progressive muscle relaxation yaitu salah satu jenis teknik relaksasi yang bertujuan memisahkan otot-otot tegang dan rileks, secara bertahap mengendurkan semua otot tubuh, dan menenangkan dengan cepat pada situasi yang menekan. (Davis, Eshelman, \& McKay, 2008). Visualisasi atau imagery adalah teknik menggunakan imajinasi untuk menenangkan dan menciptakan tempat yang aman dan rileks di dalam pikiran. Teknik ini didasarkan pada apa yang terjadi adalah yang dipikirkan, misalnya ketika individu memikirkan atau membayangkan kejadian yang sedih maka akan merasa sedih, jika membayangkan sesuatu yang mencemaskan, maka akan merasa cemas dan tegang. Sebaliknya, saat individu diminta membayangkan tempat yang indah, aman, dan nyaman, individu akan merasa rileks dan nyaman pula (Davis, Eshelman, \& McKay, 2008). Teknik lain yang dapat digunakan adalah emotional freedom techniques (EFT) atau "tapping", yaitu metode self-help untuk tubuh dan pikiran dengan mengombinasikan sentuhan lembut secara bersama-sama dengan penuh kesadaran dan perhatian pada pikiran dan perasaan. Tapping dilakukan dengan mengetukkan jari-jari pada titik akupuntur di tangan, wajah, dan tubuh sementara memfokuskan diri pada isu atau masalah yang dihadapi. EFT atau tapping dapat membantu individu mengurangi stres dan menghasilkan relaksasi umum, melepaskan dan mengubah perasaan tidak nyaman atau emosi negatif serta keluhan fisik (Hafter, Barbee, Miller, \& Shaner, 2019).
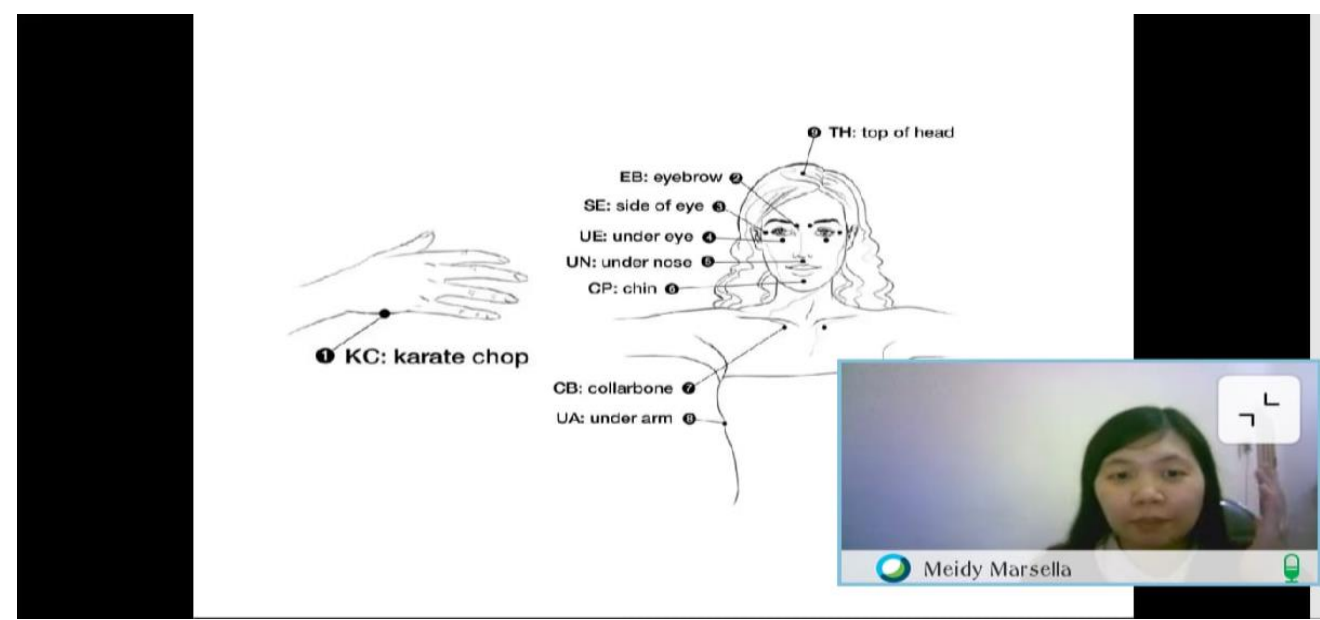

Gambar 5: Pemeragaan Teknik Meredakan Stres

Sesi terakhir setelah kedua materi disampaikan adalah sesi tanya jawab dimana peserta diberi kesempatan mengajukan pertanyaan mengenai hal-hal yang masih kurang jelas atau memberi tanggapan terhadap materi atau informasi yang diberikan. 


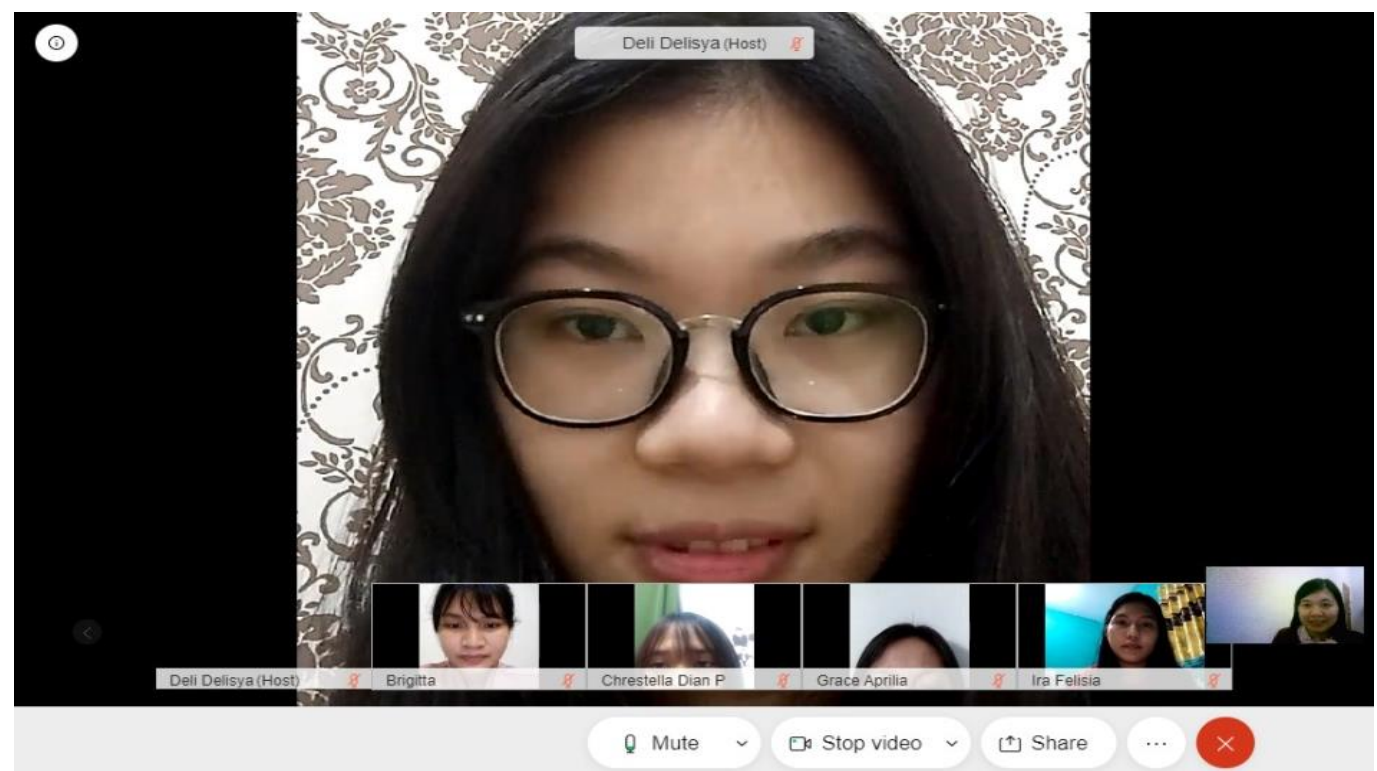

\section{Gambar 6 Sesi Tanya Jawab}

Berdasarkan evaluasi kegiatan, psikoedukasi online yang diberikan memenuhi harapan peserta yang sama dengan tujuan kegiatan yaitu memberi pengetahuan pada peserta terkait stres dan teknik untuk meredakan stres selama pandemik COVID-19. Hasil tersebut dapat dilihat pada Gambar 5 sebagai berikut:

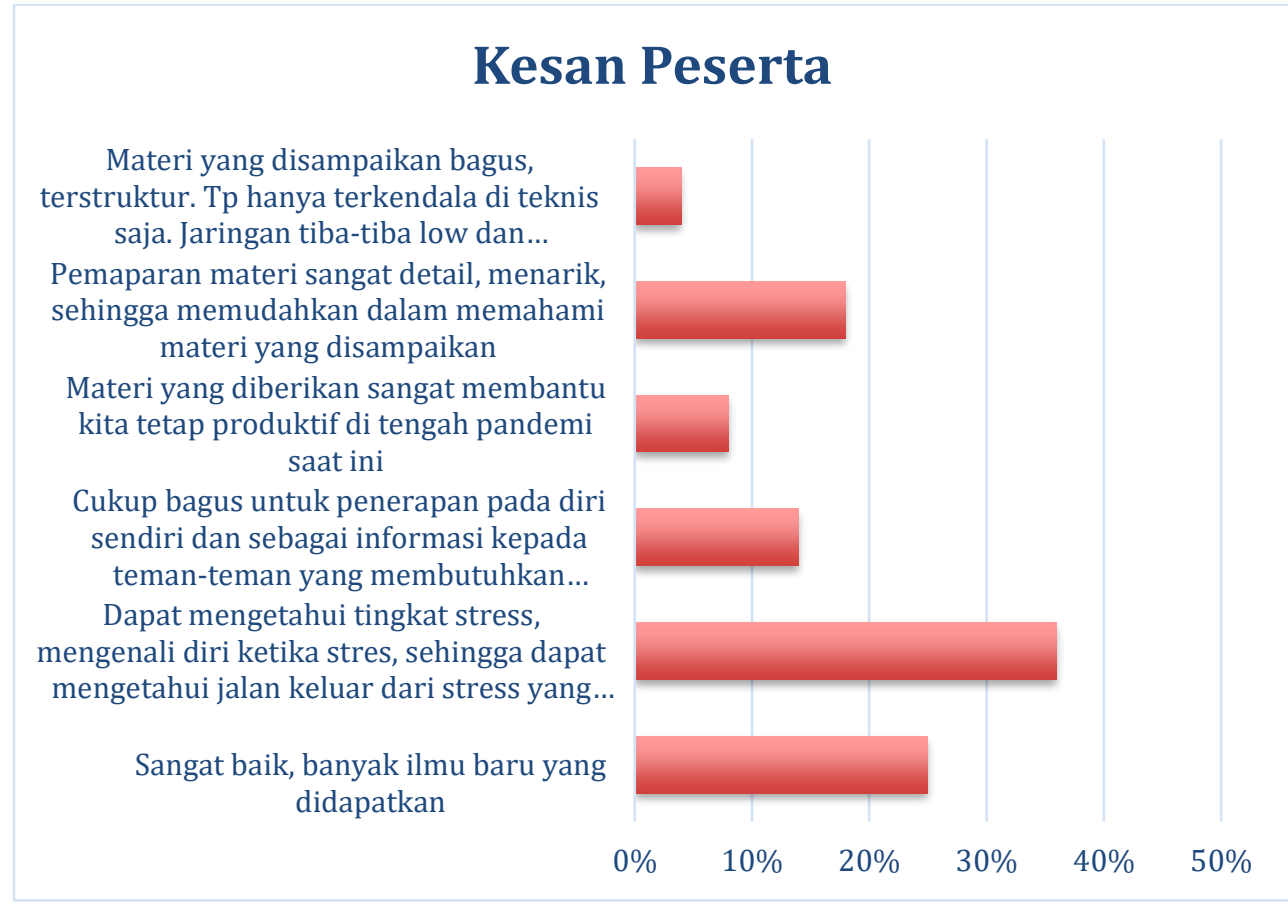

\section{Gambar 7: Grafik tentang Kesan Peserta Setelah Mengikuti Psikoedukasi Online}

Grafik di atas menunjukkan kesan peserta setelah mengikuti psikoedukasi online dimana peserta mengungkapkan mendapatkan ilmu baru, membantu peserta mengetahui tingkat stres, mengenali diri ketika stres, serta teknik yang dapat digunakan untuk menangani stres yang dialami. Manfaat lain yang dirasakan peserta yang juga sesuai 
dengan tujuan psikoedukasi online yaitu materi yang diberikan dapat membantu peserta tetap berdaya di tengah pandemik, dan informasi yang telah didapatkan akan dibagikan pada teman atau keluarga peserta karena dinilai penting dan bermanfaat. Hal ini dapat terlihat dari adanya perubahan respon pada pretest dan posttest yang diberikan kepada peserta di awal dan akhir kegiatan. Berdasarkan hasil perbandingan pretest dan posttest, peserta mengalami peningkatan pengetahuan dasar tentang stres serta menjadi lebih mengetahui teknik-teknik yang dapat dilakukan untuk meredakan stres, dimana hal tersebut merupakan pengetahuan yang baru untuk mayoritas peserta. Berdasarkan temuan ini, maka kegiatan pengabdian psikoedukasi online dapat dikatakan berhasil karena peserta mengalami peningkatan pengetahuan terkait upaya meredakan stres.

Selain manfaat terdapat pula kendala atau kekurangan selama pelaksanaan kegiatan yang perlu diperbaiki jika akan mengadakan kegiatan serupa selanjutnya, yaitu kualitas audio dan media yang digunakan serta kendala jaringan internet.

\section{KESIMPULAN}

Kegiatan pengabdian masyarakat berupa psikoedukasi online bagi masyarakat untuk meredakan stres di tengah pandemik COVID-19 dapat dilaksanakan dengan baik dan berjalan lancar. Peserta psikoedukasi online tidak hanya berasal dari Kota Makassar, melainkan juga berbagai kota di Indonesia. Tujuan kegiatan psikoedukasi online dapat tercapai yaitu dapat meningkatkan pengetahuan peserta mengenai stres dan teknik untuk meredakannya. Manfaat materi materi yang didapatkan juga tidak terbatas pada peserta karena dapat dibagikan dan digunakan oleh seluruh masyarakat yang saat ini mengalami stres sebagai salah satu dampak pandemik COVID-19. Adapun kendala teknis selama pelaksanaan perlu diantisipasi oleh pelaksana Pengabdian kepada Masyarakat jika akan melakukan kegiatan yang serupa khususnya secara daring atau online.

\section{DAFTAR PUSTAKA}

Ardiyanti, N. Bramanti, A. Mohanty, P., Narayan, K., Saputro, A. (2020). COVID19 impact on Indonesian attitudes \& behaviours: Learning for brands. Kantar Indonesia. https://www.scribd.com/document/465228941/Kantar-IndonesiaIntegrated-COVID-19-Paper

Chernikova, O., Heitzmann, N., Stadler, M., Holzberger, D., Seidel, T., Fischer, F. (2020). Simulation-based learning in Higher Education: A Meta-Analysis. Review of Educational Research. DOI: 10.3102/0034654320933544

Chen, D.D. (2017). "The meaning of stress" in Understanding stress. Routledge Taylor $\& \quad$ Francis Group. https://www.routledge.com/rsc/downloads/Mental_Health_Awareness_Week_Fr eeBook_(1).pdf

Davis, M., Eshelman, E.R., Mckay, M. (2008). The relaxation and stress reduction workbook $6^{\text {th }}$ edition. Canada: New Harbinger Publication, Inc.

Greenberg, M. (2017). The stress-proof brain: master your emotional response to stress using mindfulness and neuroplasticity. Oakland, CA: New Harbinger Publications. 
Hafter, B.M., Barbee, J., Miller, C.Z. (2019). Free tapping manual. A comprehensive introductory guide to EFT (emotional freedom techniques). UK: EFT International.

HIMPSI. (2010). Kode etik psikologi Indonesia. Jakarta: HIMPSI

Hooley, J.M., Butcher, J.N., Nock, M.K., Mineka, S. (2018). Psikologi abnormal edisi 17. Jakarta: Salemba Humanika

IASC. (2020). Briefing note on addressing mental health and psychosocial aspects of COVID 19 Outbreak - Version 1.1. Inter-Agency Standing Committee Reference group for Mental Health and Psychosocial Support in Emergency Settings. http://www.socialserviceworkforce.org/system/files/resource/files/Briefing-NoteAddressing-Mental-Health-and-PSS-COVID-19.pdf

Maryam, S., Yazdani, Z, Valibeigi, A. (2020). The effect of online multimedia psychoeducational interventions on the perceived stress and resilience of hospitalized patients with COVID-19: A quasi-experimental study. Research Square. https://doi.org/10.21203/rs.3.rs-36980/v1

McLain, M. (2019). Developing perspectives on 'the demonstration' as a signature pedagogy in design and technology education. International Journal of Technology and Design Education 31:3-26. https://doi.org/10.1007/s10798-01909545-1

Murphy, R., Sharma, N. (2010). What don't we know about interactive lectures? Seminar.net: International Journal of Media, Technology and Lifelong Learning 6(2). http://seminar.net/backup/index.php/volume-6-issue-1-2010/135-what-dontwe-know-about-interactive-lectures

Nuraini, R. (2020, 2 Maret). Kasus COVID-19 pertama, masyarakat jangan panik. Indonesia.GO.ID. Diambil dari https://indonesia.go.id/narasi/indonesia-dalamangka/ekonomi/kasus-covid-19-pertama-masyarakat-jangan-panik

NYC Health. 2020. Coping with stress and social distancing during the coronavirus (COVID-19) outbreak. NYC Health Department. https://www.gnyha.org/wpcontent/uploads/2020/05/Coping-with-Stress-and-Social-Distancing-

DOHMH.pdf

Prabowo, D. (2020, 19 Maret). Masyarakat diimbau patuhi patuhi imbauan "pentingnya social distancing”. Kompas.com. Diambil "pari https://nasional.kompas.com/read/2020/03/19/12381841/masyarakat-diimbaupatuhi-imbauan-penting-soal-social-distancing

Purdue University Global. 2020. Online learning: 4 Common challenges facing online learners and how to overcome them. https://www.purdueglobal.edu/

Scott, E. (2020). What is stress? https://www.verywellmind.com/stress-and-health3145086 
Smith, G., Harman, S., Brenner, K (2020). Flattening the curve of distress: A publicfacing webinar for psychoeducation during COVID-19. Pateint Experience Journal, 7 (2), 151-155. https://pxjournal.org/journal/vol7/iss2/29

Supratiknya, A. (2011). Psikoedukasi: Merancang program dan modul. Yogyakarta: Universitas Sanata Dharma.

Taylor, S. (2019). The psychology of pandemics: Preparing for the next global outbreak of infectious disease. UK: Cambridge Scholars Publishing.

Torales, J. O'Higgins, M., Castaldelli-Maia, J.M., Ventriglio, A. (2020). The outbreak of covid 19 coronavirus and its impact on global mental health. International Journal of Social Psychiatry, 66 (4), 317-320. https://journals.sagepub.com/doi/full/10.1177/0020764020915212

World Health Organization. (2020). Mental health and psychosocial considerations during the COVID-19 outbreak. https://www.who.int/docs/defaultsource/coronaviruse/mental-health-considerations.pdf?sfvrsn=6d3578af_10

Yakovleva, N.O., Yakovlev, E.V. (2014). Interactive teaching methods in contemporary higher education. Pasific Science Review volume 16, Issue 2 pages 75-80. https://doi.org/10.1016/j.pscr.2014.08.016 